\title{
Prokineticin receptors (version 2019.4) in the IUPHAR/BPS Guide to Pharmacology Database
}

\author{
Rebecca Hills ${ }^{1}$, Philippe Rondard ${ }^{2}$, Oualid Sbai ${ }^{2}$ and Qun-Yong Zhou ${ }^{3}$ \\ 1. University of Edinburgh, UK \\ 2. Université de Montpellier, France \\ 3. University of California Irvine, USA
}

\begin{abstract}
Prokineticin receptors, $\mathrm{PKR}_{1}$ and $\mathrm{PKR}_{2}$ (provisional nomenclature as recommended by NC-IUPHAR [23]) respond to the cysteine-rich 81-86 amino-acid peptides prokineticin-1 (also known as endocrine gland-derived vascular endothelial growth factor, mambakine) and prokineticin-2 (protein Bv8 homologue). An orthologue of PROK1 from black mamba (Dendroaspis polylepis) venom, mamba intestinal toxin 1 MIT1, [65]) is a potent, non-selective agonist at prokineticin receptors [41], while Bv8, an orthologue of PROK2 from amphibians (Bombina sp., [44]), is equipotent at recombinant $\mathrm{PKR}_{1}$ and $\mathrm{PKR}_{2}$ [48], and has high potency in macrophage chemotaxis assays, which are lost in $\mathrm{PKR}_{1}$-null mice.
\end{abstract}

\section{Contents}

This is a citation summary for Prokineticin receptors in the Guide to Pharmacology database (GtoPdb). It exists purely as an adjunct to the database to facilitate the recognition of citations to and from the database by citation analyzers. Readers will almost certainly want to visit the relevant sections of the database which are given here under database links.

GtoPdb is an expert-driven guide to pharmacological targets and the substances that act on them. GtoPdb is a reference work which is most usefully represented as an on-line database. As in any publication this work should be appropriately cited, and the papers it cites should also be recognized. This document provides a citation for the relevant parts of the database, and also provides a reference list for the research cited by those parts.

Please note that the database version for the citations given in GtoPdb are to the most recent preceding version in which the family or its subfamilies and targets were substantially changed. The links below are to the current version. If you need to consult the cited version, rather than the most recent version, please contact the GtoPdb curators.

\section{Database links}

Prokineticin receptors

http://www.guidetopharmacology.org/GRAC/FamilyDisplayForward?familyld=56

Introduction to Prokineticin receptors

http://www.guidetopharmacology.org/GRAC/FamilyIntroductionForward?familyld=56 
Receptors

$\mathrm{PKR}_{1}$

http://www.guidetopharmacology.org/GRAC/ObjectDisplayForward?objectld=335

$\mathrm{PKR}_{2}$

http://www.guidetopharmacology.org/GRAC/ObjectDisplayForward?objectld=336

\section{References}

1. Abreu AP, Noel SD, Xu S, Carroll RS, Latronico AC and Kaiser UB. (2012) Evidence of the importance of the first intracellular loop of prokineticin receptor 2 in receptor function. Mol. Endocrinol. 26: 1417-27 [PMID:22745195]

2. Abreu AP, Trarbach EB, de Castro M, Frade Costa EM, Versiani B, Matias Baptista MT, Garmes HM, Mendonca BB and Latronico AC. (2008) Loss-of-function mutations in the genes encoding prokineticin-2 or prokineticin receptor-2 cause autosomal recessive Kallmann syndrome. J. Clin. Endocrinol. Metab. 93: 4113-8 [PMID:18682503]

3. Balboni G, Lazzari I, Trapella C, Negri L, Lattanzi R, Giannini E, Nicotra A, Melchiorri P, Visentin S and Nuccio CD et al.. (2008) Triazine compounds as antagonists at Bv8-prokineticin receptors.J. Med. Chem. 51: 7635-9 [PMID:19006379]

4. Battersby S, Critchley HO, Morgan K, Millar RP and Jabbour HN. (2004) Expression and regulation of the prokineticins (endocrine gland-derived vascular endothelial growth factor and Bv8) and their receptors in the human endometrium across the menstrual cycle. J. Clin. Endocrinol. Metab. 89: 2463-9 [PMID:15126578]

5. Beale K, Gardiner JV, Bewick GA, Hostomska K, Patel NA, Hussain SS, Jayasena CN, Ebling FJ, Jethwa $\mathrm{PH}$ and Prosser HM et al.. (2013) Peripheral administration of prokineticin 2 potently reduces food intake and body weight in mice via the brainstem. Br. J. Pharmacol. 168: 403-10 [PMID:22935107]

6. Boulberdaa M, Turkeri G, Urayama K, Dormishian M, Szatkowski C, Zimmer L, Messaddeq N, Laugel V, Dollé P and Nebigil CG. (2011) Genetic inactivation of prokineticin receptor-1 leads to heart and kidney disorders. Arterioscler. Thromb. Vasc. Biol. 31: 842-50 [PMID:21273561]

7. Bullock CM, Li JD and Zhou QY. (2004) Structural determinants required for the bioactivities of prokineticins and identification of prokineticin receptor antagonists. Mol. Pharmacol. 65: 582-8 [PMID:14978236]

8. Canto P, Munguía P, Söderlund D, Castro JJ and Méndez JP. (2009) Genetic analysis in patients with Kallmann syndrome: coexistence of mutations in prokineticin receptor 2 and KAL1. J. Androl. 30: 41-5 [PMID:18723471]

9. Caronia LM, Martin C, Welt CK, Sykiotis GP, Quinton R, Thambundit A, Avbelj M, Dhruvakumar S, Plummer $L$ and Hughes VA et al.. (2011) A genetic basis for functional hypothalamic amenorrhea.N. Engl. J. Med. 364: 215-25 [PMID:21247312]

10. Chan YM, de Guillebon A, Lang-Muritano M, Plummer L, Cerrato F, Tsiaras S, Gaspert A, Lavoie HB, Wu $\mathrm{CH}$ and Crowley Jr WF et al.. (2009) GNRH1 mutations in patients with idiopathic hypogonadotropic hypogonadism. Proc. Natl. Acad. Sci. U.S.A. 106: 11703-8 [PMID:19567835]

11. Chen J, Kuei C, Sutton S, Wilson S, Yu J, Kamme F, Mazur C, Lovenberg T and Liu C. (2005) Identification and pharmacological characterization of prokineticin 2 beta as a selective ligand for prokineticin receptor 1. Mol. Pharmacol. 67: 2070-6 [PMID:15772293]

12. Cheng MY, Bullock CM, Li C, Lee AG, Bermak JC, Belluzzi J, Weaver DR, Leslie FM and Zhou QY. (2002) Prokineticin 2 transmits the behavioural circadian rhythm of the suprachiasmatic nucleus. Nature 417: 405-410 [PMID:12024206]

13. Cheng MY, Lee AG, Culbertson C, Sun G, Talati RK, Manley NC, Li X, Zhao H, Lyons DM and Zhou QYet al.. (2012) Prokineticin 2 is an endangering mediator of cerebral ischemic injury.Proc. Natl. Acad. Sci. U.S.A. 109: 5475-80 [PMID:22431614]

14. Cole LW, Sidis Y, Zhang C, Quinton R, Plummer L, Pignatelli D, Hughes VA, Dwyer AA, Raivio T and Hayes FJ et al.. (2008) Mutations in prokineticin 2 and prokineticin receptor 2 genes in human 
gonadotrophin-releasing hormone deficiency: molecular genetics and clinical spectrum. J. Clin. Endocrinol. Metab. 93: 3551-9 [PMID:18559922]

15. Cook IH, Evans J, Maldonado-Pérez D, Critchley HO, Sales KJ and Jabbour HN. (2010) Prokineticin-1 (PROK1) modulates interleukin (IL)-11 expression via prokineticin receptor 1 (PROKR1) and the calcineurin/NFAT signalling pathway. Mol. Hum. Reprod. 16: 158-69 [PMID:19801577]

16. Cottrell GT, Zhou QY and Ferguson AV. (2004) Prokineticin 2 modulates the excitability of subfornical organ neurons. J. Neurosci. 24: 2375-9 [PMID:15014112]

17. Denison FC, Battersby S, King AE, Szuber M and Jabbour HN. (2008) Prokineticin-1: a novel mediator of the inflammatory response in third-trimester human placenta. Endocrinology 149: 3470-7 [PMID:18372330]

18. Dodé $C$ and Rondard P. (2013) PROK2/PROKR2 Signaling and Kallmann Syndrome.Front Endocrinol (Lausanne) 4: 19 [PMID:23596439]

19. Dodé C, Teixeira L, Levilliers J, Fouveaut C, Bouchard P, Kottler ML, Lespinasse J, Lienhardt-Roussie A, Mathieu M and Moerman A et al.. (2006) Kallmann syndrome: mutations in the genes encoding prokineticin-2 and prokineticin receptor-2. PLoS Genet. 2: e175 [PMID:17054399]

20. Dorsch M, Qiu Y, Soler D, Frank N, Duong T, Goodearl A, O'Neil S, Lora J and Fraser CC. (2005) PK1/EG-VEGF induces monocyte differentiation and activation. J. Leukoc. Biol. 78: 426-34 [PMID:15908459]

21. Dwyer AA, Hayes FJ, Plummer L, Pitteloud N and Crowley Jr WF. (2010) The long-term clinical follow-up and natural history of men with adult-onset idiopathic hypogonadotropic hypogonadism. J. Clin. Endocrinol. Metab. 95: 4235-43 [PMID:20591981]

22. Evans J, Catalano RD, Morgan K, Critchley HO, Millar RP and Jabbour HN. (2008) Prokineticin 1 signaling and gene regulation in early human pregnancy. Endocrinology 149: 2877-87 [PMID:18339712]

23. Foord SM, Bonner TI, Neubig RR, Rosser EM, Pin JP, Davenport AP, Spedding M and Harmar AJ. (2005) International Union of Pharmacology. XLVI. G protein-coupled receptor list. Pharmacol. Rev. 57: 279-88 [PMID:15914470]

24. Franchi S, Giannini E, Lattuada D, Lattanzi R, Tian H, Melchiorri P, Negri L, Panerai AE and Sacerdote P. (2008) The prokineticin receptor agonist Bv8 decreases IL-10 and IL-4 production in mice splenocytes by activating prokineticin receptor-1. BMC Immunol. 9: 60 [PMID:18957080]

25. Gasser A, Brogi S, Urayama K, Nishi T, Kurose H, Tafi A, Ribeiro N, Désaubry L and Nebigil CG. (2015) Discovery and cardioprotective effects of the first non-Peptide agonists of the $G$ protein-coupled prokineticin receptor-1. PLOS ONE 10: e0121027 [PMID:25831128]

26. Guilini C, Urayama K, Turkeri G, Dedeoglu DB, Kurose H, Messaddeq N and Nebigil CG. (2010) Divergent roles of prokineticin receptors in the endothelial cells: angiogenesis and fenestration. Am. J. Physiol. Heart Circ. Physiol. 298: H844-52 [PMID:20023120]

27. Hoffmann P, Feige JJ and Alfaidy N. (2006) Expression and oxygen regulation of endocrine gland-derived vascular endothelial growth factor/prokineticin-1 and its receptors in human placenta during early pregnancy. Endocrinology 147: 1675-84 [PMID:16384869]

28. Hoogerwerf WA. (2006) Prokineticin 1 inhibits spontaneous giant contractions in the murine proximal colon through nitric oxide release. Neurogastroenterol. Motil. 18: 455-63 [PMID:16700725]

29. Jacobson O, Weiss ID, Niu G, Balboni G, Congiu C, Onnis V, Kiesewetter DO, Lattanzi R, Salvadori S and Chen X. (2011) Prokineticin receptor 1 antagonist PC-10 as a biomarker for imaging inflammatory pain. J. Nucl. Med. 52: 600-7 [PMID:21421710]

30. Khusal KG, Tonelli RR, Mattos EC, Soares CO, Di Genova BM, Juliano MA, Urias U, Colli W and Alves MJ. (2015) Prokineticin receptor identified by phage display is an entry receptor for Trypanosoma cruzi into mammalian cells. Parasitol. Res. 114: 155-65 [PMID:25324134]

31. Kisliouk T, Levy N, Hurwitz A and Meidan R. (2003) Presence and regulation of endocrine gland vascular endothelial growth factor/prokineticin-1 and its receptors in ovarian cells. J Clin Endocrinol Metab 88: 3700 3707 [PMID:12915658]

32. Lattanzi R, Congui C, Onnis V, Deplano A, Salvadori S, Marconi V, Maftei D, Francisco A, Ambrosio C, Casella I, Costa T, Calatabiano G, Matsoukas MT, Balboni G and Negri L. (2014) Halogenated 
triazinediones behave as antagonists of $\mathrm{PKR}_{1}$ : in vitro and in vivo pharmacological characterization. Int. J. Pharm. Sci. Res 5: 5066-5074

33. LeCouter J, Kowalski J, Foster J, Hass P, Zhang Z, Dillard-Telm L, Frantz G, Rangell L, DeGuzman L and Keller GA et al.. (2001) Identification of an angiogenic mitogen selective for endocrine gland endothelium. Nature 412: 877-84 [PMID:11528470]

34. LeCouter J, Lin R, Frantz G, Zhang Z, Hillan K and Ferrara N. (2003) Mouse endocrine gland-derived vascular endothelial growth factor: a distinct expression pattern from its human ortholog suggests different roles as a regulator of organ-specific angiogenesis. Endocrinology 144: 2606-16 [PMID:12746324]

35. LeCouter J, Lin R, Tejada M, Frantz G, Peale F, Hillan KJ and Ferrara N. (2003) The endocrine-glandderived VEGF homologue Bv8 promotes angiogenesis in the testis: Localization of Bv8 receptors to endothelial cells. Proc. Natl. Acad. Sci. U.S.A. 100: 2685-90 [PMID:12604792]

36. LeCouter J, Zlot C, Tejada M, Peale F and Ferrara N. (2004) Bv8 and endocrine gland-derived vascular endothelial growth factor stimulate hematopoiesis and hematopoietic cell mobilization. Proc. Natl. Acad. Sci. U.S.A. 101: 16813-8 [PMID:15548611]

37. Li M, Bullock CM, Knauer DJ, Ehlert FJ and Zhou QY. (2001) Identification of two prokineticin cDNAs: recombinant proteins potently contract gastrointestinal smooth muscle. Mol Pharmacol 59: 692-698 [PMID:11259612]

38. Lin DC, Bullock CM, Ehlert FJ, Chen JL, Tian H and Zhou QY. (2002) Identification and molecular characterization of two closely related $\mathrm{G}$ protein-coupled receptors activated by prokineticins/endocrine gland vascular endothelial growth factor. J. Biol. Chem. 277: 19276-80 [PMID:11886876]

39. Lin R, LeCouter J, Kowalski J and Ferrara N. (2002) Characterization of endocrine gland-derived vascular endothelial growth factor signaling in adrenal cortex capillary endothelial cells. J. Biol. Chem. 277: 8724-9 [PMID:11751915]

40. Martucci C, Franchi S, Giannini E, Tian H, Melchiorri P, Negri L and Sacerdote P. (2006) Bv8, the amphibian homologue of the mammalian prokineticins, induces a proinflammatory phenotype of mouse macrophages. Br. J. Pharmacol. 147: 225-34 [PMID:16299550]

41. Masuda Y, Takatsu Y, Terao Y, Kumano S, Ishibashi Y, Suenaga M, Abe M, Fukusumi S, Watanabe T and Shintani $Y$ et al.. (2002) Isolation and identification of EG-VEGF/prokineticins as cognate ligands for two orphan G-protein-coupled receptors. Biochem. Biophys. Res. Commun. 293: 396-402 [PMID:12054613]

42. Matsumoto S, Yamazaki C, Masumoto KH, Nagano M, Naito M, Soga T, Hiyama H, Matsumoto M, Takasaki J and Kamohara M et al.. (2006) Abnormal development of the olfactory bulb and reproductive system in mice lacking prokineticin receptor PKR2. Proc. Natl. Acad. Sci. U.S.A. 103: 4140-5 [PMID:16537498]

43. McCabe MJ, Gaston-Massuet C, Gregory LC, Alatzoglou KS, Tziaferi V, Sbai O, Rondard P, Masumoto $\mathrm{KH}$, Nagano M and Shigeyoshi Y et al.. (2013) Variations in PROKR2, but not PROK2, are associated with hypopituitarism and septo-optic dysplasia. J. Clin. Endocrinol. Metab. 98: E547-57 [PMID:23386640]

44. Mollay C, Wechselberger C, Mignogna G, Negri L, Melchiorri P, Barra D and Kreil G. (1999) Bv8, a small protein from frog skin and its homologue from snake venom induce hyperalgesia in rats. Eur. J. Pharmacol. 374: 189-96 [PMID:10422759]

45. Monnier C, Dodé C, Fabre L, Teixeira L, Labesse G, Pin JP, Hardelin JP and Rondard P. (2009) PROKR2 missense mutations associated with Kallmann syndrome impair receptor signalling activity. Hum. Mol. Genet. 18: 75-81 [PMID:18826963]

46. Moya-Plana A, Villanueva C, Laccourreye O, Bonfils P and de Roux N. (2013) PROKR2 and PROK2 mutations cause isolated congenital anosmia without gonadotropic deficiency. Eur. J. Endocrinol. 168: 317 [PMID:23082007]

47. Negri L, Lattanzi R, Giannini E, Colucci M, Margheriti F, Melchiorri P, Vellani V, Tian H, De Felice M and Porreca F. (2006) Impaired nociception and inflammatory pain sensation in mice lacking the prokineticin receptor PKR1: focus on interaction between PKR1 and the capsaicin receptor TRPV1 in pain behavior. J. Neurosci. 26: 6716-27 [PMID:16793879] 
48. Negri L, Lattanzi R, Giannini E, Colucci MA, Mignogna G, Barra D, Grohovaz F, Codazzi F, Kaiser A and Kreil $\mathrm{G}$ et al.. (2005) Biological activities of Bv8 analogues.Br. J. Pharmacol. 146: 625-32 [PMID:16113687]

49. Negri L, Lattanzi R, Giannini E, De Felice M, Colucci A and Melchiorri P. (2004) Bv8, the amphibian homologue of the mammalian prokineticins, modulates ingestive behaviour in rats. Br. J. Pharmacol. 142: 181-91 [PMID:15066905]

50. Negri L, Lattanzi R, Giannini E, Metere A, Colucci M, Barra D, Kreil G and Melchiorri P. (2002) Nociceptive sensitization by the secretory protein Bv8. Br. J. Pharmacol. 137: 1147-54 [PMID:12466223]

51. Ng KL, Li JD, Cheng MY, Leslie FM, Lee AG and Zhou QY. (2005) Dependence of olfactory bulb neurogenesis on prokineticin 2 signaling. Science 308: 1923-7 [PMID:15976302]

52. Ngan ES, Lee KY, Sit FY, Poon HC, Chan JK, Sham MH, Lui VC and Tam PK. (2007) Prokineticin-1 modulates proliferation and differentiation of enteric neural crest cells. Biochim. Biophys. Acta 1773: 53645 [PMID:17324478]

53. O'Hayre M, Vázquez-Prado J, Kufareva I, Stawiski EW, Handel TM, Seshagiri S and Gutkind JS. (2013) The emerging mutational landscape of $G$ proteins and G-protein-coupled receptors in cancer. Nat. Rev. Cancer 13: 412-24 [PMID:23640210]

54. Parker R, Liu M, Eyre HJ, Copeland NG, Gilbert DJ, Crawford J, Sutherland GR, Jenkins NA and Herzog H. (2000) Y-receptor-like genes GPR72 and GPR73: molecular cloning, genomic organisation and assignment to human chromosome 11q21.1 and 2p14 and mouse chromosome 9 and 6. Biochim. Biophys. Acta 1491: 369-75 [PMID:10760605]

55. Prosser HM, Bradley A and Caldwell MA. (2007) Olfactory bulb hypoplasia in Prokr2 null mice stems from defective neuronal progenitor migration and differentiation. Eur. J. Neurosci. 26: 3339-44 [PMID:18052978]

56. Prosser HM, Bradley A, Chesham JE, Ebling FJ, Hastings MH and Maywood ES. (2007) Prokineticin receptor 2 (Prokr2) is essential for the regulation of circadian behavior by the suprachiasmatic nuclei. Proc. Natl. Acad. Sci. U.S.A. 104: 648-53 [PMID:17202262]

57. Puverel S, Nakatani H, Parras $C$ and Soussi-Yanicostas N. (2009) Prokineticin receptor 2 expression identifies migrating neuroblasts and their subventricular zone transient-amplifying progenitors in adult mice. J. Comp. Neurol. 512: 232-42 [PMID:19003791]

58. Qiu CY, Liu YQ, Qiu F, Wu J, Zhou QY and Hu WP. (2012) Prokineticin 2 potentiates acid-sensing ion channel activity in rat dorsal root ganglion neurons. J Neuroinflammation 9: 108 [PMID:22642848]

59. Raivio T, Avbelj M, McCabe MJ, Romero CJ, Dwyer AA, Tommiska J, Sykiotis GP, Gregory LC, Diaczok D and Tziaferi $V$ et al.. (2012) Genetic overlap in Kallmann syndrome, combined pituitary hormone deficiency, and septo-optic dysplasia. J. Clin. Endocrinol. Metab. 97: E694-9 [PMID:22319038]

60. Ralbovsky JL, Lisko JG, Palmer JM, Mabus J, Chevalier KM, Schulz MJ, Dyatkin AB, Miskowski TA, Coats SJ and Hornby P et al.. (2009) Triazinediones as prokineticin 1 receptor antagonists. Part 1: SAR, synthesis and biological evaluation. Bioorg. Med. Chem. Lett. 19: 2661-3 [PMID:19375913]

61. Ren P, Zhang H, Qiu F, Liu YQ, Gu H, O'Dowd DK, Zhou QY and Hu WP. (2011) Prokineticin 2 regulates the electrical activity of rat suprachiasmatic nuclei neurons. PLoS ONE 6: e20263 [PMID:21687716]

62. Reynaud R, Jayakody SA, Monnier C, Saveanu A, Bouligand J, Guedj AM, Simonin G, Lecomte P, Barlier A and Rondard $\mathrm{P}$ et al.. (2012) PROKR2 variants in multiple hypopituitarism with pituitary stalk interruption. J. Clin. Endocrinol. Metab. 97: E1068-73 [PMID:22466334]

63. Ruiz-Ferrer M, Torroglosa A, Núñez-Torres R, de Agustín JC, Antiñolo G and Borrego S. (2011) Expression of PROKR1 and PROKR2 in human enteric neural precursor cells and identification of sequence variants suggest a role in HSCR. PLOS ONE 6: e23475 [PMID:21858136]

64. Sarfati J, Guiochon-Mantel A, Rondard P, Arnulf I, Garcia-Piñero A, Wolczynski S, Brailly-Tabard S, Bidet M, Ramos-Arroyo M and Mathieu M et al.. (2010) A comparative phenotypic study of kallmann syndrome patients carrying monoallelic and biallelic mutations in the prokineticin 2 or prokineticin receptor 2 genes. J. Clin. Endocrinol. Metab. 95: 659-69 [PMID:20022991]

65. Schweitz H, Pacaud P, Diochot S, Moinier D and Lazdunski M. (1999) MIT(1), a black mamba toxin with a new and highly potent activity on intestinal contraction. FEBS Lett. 461: 183-8 [PMID:10567694] 
66. Sinisi AA, Asci R, Bellastella G, Maione L, Esposito D, Elefante A, De Bellis A, Bellastella A and Iolascon A. (2008) Homozygous mutation in the prokineticin-receptor2 gene (Val274Asp) presenting as reversible Kallmann syndrome and persistent oligozoospermia: case report. Hum. Reprod. 23: 2380-4 [PMID:18596028]

67. Soga T, Matsumoto Si, Oda T, Saito T, Hiyama H, Takasaki J, Kamohara M, Ohishi T, Matsushime $H$ and Furuichi K. (2002) Molecular cloning and characterization of prokineticin receptors. Biochim. Biophys. Acta 1579: 173-9 [PMID:12427552]

68. Su MT, Lin SH, Chen YC, Wu LW and Kuo PL. (2013) Prokineticin receptor variants (PKR1-I379V and PKR2-V331M) are protective genotypes in human early pregnancy. Reproduction 146: 63-73 [PMID:23687280]

69. Svingen T, McClelland KS, Masumoto K, Sujino M, Nagano M, Shigeyoshi Y and Koopman P. (2011) Prokr2-deficient mice display vascular dysmorphology of the fetal testes: potential implications for Kallmann syndrome aetiology. Sex Dev 5: 294-303 [PMID:22223120]

70. Tabata S, Goi T, Nakazawa T, Kimura Y, Katayama K and Yamaguchi A. (2013) Endocrine gland-derived vascular endothelial growth factor strengthens cell invasion ability via prokineticin receptor 2 in colon cancer cell lines. Oncol. Rep. 29: 459-63 [PMID:23135359]

71. Tommiska J, Toppari J, Vaaralahti K, Känsäkoski J, Laitinen EM, Noisa P, Kinnala A, Niinikoski H and Raivio T. (2013) PROKR2 mutations in autosomal recessive Kallmann syndrome. Fertil. Steril. 99: 815-8 [PMID:23200691]

72. Urayama K, Guilini C, Messaddeq N, Hu K, Steenman M, Kurose H, Ert G and Nebigil CG. (2007) The prokineticin receptor-1 (GPR73) promotes cardiomyocyte survival and angiogenesis. FASEB J. 21: 2980 93 [PMID:17442730]

73. Urayama K, Guilini C, Turkeri G, Takir S, Kurose H, Messaddeq N, Dierich A and Nebigil CG. (2008) Prokineticin receptor-1 induces neovascularization and epicardial-derived progenitor cell differentiation. Arterioscler. Thromb. Vasc. Biol. 28: 841-9 [PMID:18421008]

74. Vellani V, Colucci M, Lattanzi R, Giannini E, Negri L, Melchiorri P and McNaughton PA. (2006) Sensitization of transient receptor potential vanilloid 1 by the prokineticin receptor agonist Bv8. J. Neurosci. 26: 5109-16 [PMID:16687502]

75. Wade PR, Palmer JM, Mabus J, Saunders PR, Prouty S, Chevalier K, Gareau MG, McKenney S and Hornby PJ. (2010) Prokineticin-1 evokes secretory and contractile activity in rat small intestine. Neurogastroenterol. Motil. 22: e152-61 [PMID:19930539]

76. Xiong YC, Li XM, Wang XJ, Liu YQ, Qiu F, Wu D, Gan YB, Wang BH and Hu WP. (2010) Prokineticin 2 suppresses GABA-activated current in rat primary sensory neurons. Neuropharmacology 59: 589-94 [PMID:20800074]

77. Yuill EA, Hoyda TD, Ferri CC, Zhou QY and Ferguson AV. (2007) Prokineticin 2 depolarizes paraventricular nucleus magnocellular and parvocellular neurons. Eur. J. Neurosci. 25: 425-34 [PMID:17284183] 